\title{
Ženski paradoks modernizacije
}

Vjeran KATUNARIĆ

Odjel za sociologiju, Sveučilište u Zadru, Hrvatska

vjeran.katunaric@zg.t-com.hr

- Inga Tomić-Koludrović. Pomak prema modernosti: žene u Hrvatskoj u razdoblju »zrele« tranzicije. Zagreb: Naklada Jesenski i Turk i Hrvatsko sociološko društvo, 2015, 327 str.

» [A]ko postoji nešto poput formule ženskog bića, ona se poklapa s [...] bićem glumačke umjetnosti [...]. To se tako lako, premda pogrešno, smatra nedostatkom, budući da predstavlja vlastiti pozitivan karakter, polarno suprotstavljen muškome, u glumačkoj je umjetnosti krajnja unutarnja struktura rezultata.« (Simmel, 2001: 187-188).

\section{Uvod}

Simmelova usporedba ženske kulture s glumačkom umjetnošću podsjeća nas na pripovjedačku mnogolikost Šeherezade u Tisuću i jednoj noći, »ženu s tisuću lica« u filmova Eleanor Parker, barbadošku pjevačicu i »modnu kameleonku« Rihanne, i mnoge druge. Ta glumačka strast nije, međutim, samo dio umjetničke pozornice, nego i mnogo veće i često nevidljive pozornice života žena. U njoj ne samo da se prikazuju i razotkrivaju, nego i prerušavaju i skrivaju potencijali žena, što sačinjava bezbrojne epizode dugog puta emancipacije. Taj je proces emancipacije teško raspoznati ili se to nerado čini kad je riječ o opisima moderne društvene epohe, osobito starijim opisima koji, na temelju nedovoljno istraženih društvenih i političkih činjenica, proces modernizacije opisuju kao jednosmjernu ulicu što iz despocije vodi u demokraciju.

$\mathrm{Na}$ ta razmišljanja navodi nas poticajna studija Inge Tomić-Koludrović Pomak prema modernosti. Žene u Hrvatskoj u razdoblju zrele tranzicije. Knjiga u većem dijelu problematizira stereotipnu predodžbu o tradicionalnoj i modernoj ženi. Iako je dosad objavljeno mnogo istraživačkih radova o modernizaciji, društvima u tranziciji i društvenom položaju žena - premda relativno malo o ženi i modernizaciji u hrvatskom društvu - Pomak prema modernosti zaslužuje pozornost upravo zbog dekonstrukcije stereotipa i njihove zamjene konceptualnom terminologijom koja označava više različitih društvenih tipova žena u suvremenoj Hrvatskoj, a vjero- 
jatno i u drugim društvima na sličnim stupnjevima modernizacije. Time dovodi u pitanje shvaćanja o suvremenim procesima emancipacije žena kao pravocrtnom prijelazu iz patrijarhalno-hijerarhijskog u egalitarno-demokratski sustav. Osim niza drugih pitanja - kao, na primjer, je li, gledajući sveukupno, bivši socijalizam pružao ženama veće društvene mogućnosti od suvremenog kapitalizma, koji je u Hrvatskoj očito još u ranoj fazi (?) - nameće se već spomenuto pitanje (o kojem je više riječi u posljednjem dijelu osvrta), naime, je li emancipacija žena isključivo moderan fenomen, neki oblik slobode i jednakosti koji nema svoje korijene $u$ prethodnim tradicijama, nego je plod radikalnoga, revolucionarnog diskontinuiteta stvorenog zahvaljujući potencijalima (samo)preobrazbe ranoga liberalnog kapitalizma koji, kao jednu od posljedica svog repertoara potražnje, izvlači žene iz vjekovnoga kućnog ropstva na otvoreno tržište rada?

Ovaj osvrt ima dva cilja. Prvi je pokazati kako se zahvaljujući autoričinoj analizi mogu opovrgnuti i tradicionalni i moderni stereotip žena, nazovimo ih nazadnjačkim i naprednjačkim. Drugi je cilj pokušati potpunije objasniti središnji paradoks društvene modernizacije u Hrvatskoj, što se odnosi na opadanje rodnog konzervativizma u jeku porasta svih drugih konzervativizama od kraja 20. stoljeća, a što je možda povezano s evolucijski dugotrajnijim procesom društvene emancipacije žena.

\section{Analitikom protiv stereotipa}

Najprije nekoliko zapažanja o svrhovitosti najvećeg dijela knjige u kojem se nalazi, između ostaloga, 89 tablica sa statističkim podacima i 18 slika (grafičkih prikaza i zemljopisnih karata, u čijim je izradama sudjelovala Željka Zdravković). Takva podrobna analiza ima za cilj prikazati stavove žena o sebi i društvu u suvremenoj Hrvatskoj, iz čega proizlazi dosta složena slika, svakako sadržajnija od stereotipnih, bilo banalnih ili akademskih. Među prve pripadaju, na primjer, izjave o ženama općenito kao »drugotnima«, mladim ženama kao »štracama«, poruke koje dolaze iz Crkve, milenijske institucije od koje je starija samo njezina mizoginost, što drastično odudara od činjenice da u svim epohama žene čine najveći dio pastve. Akademski stereotip o ženi plod je emancipacijskog svjetonazora europskoga 19. stoljeća, koje emancipaciju žena smatra isključivo posljedicom modernizacije $\mathrm{i}$ to njezinom pratećom posljedicom. Ta slika nije načelno pogrešna, osobito ne $u$ globalu, budući da su žene doista slobodnije i žive udobnije na Zapadu nego u ostalim dijelovima svijeta. Ali, to je slika koja proizlazi iz površnog sagledavanja krivulja na grafikonu, prije svega varijacija koje nužno ne vode u istom smjeru i koje se, zašto ne, mogu premetnuti u neku drugu pravilnost s onu stranu dihotomije Zapad - Istok ili Sjever - Jug.

Ovdje raspravljamo o dvjema takvim varijacijama, koristeći se rezultatima analize Inge Tomić-Koludrović, situacije u Hrvatskoj. Jednu varijaciju autorica opisuje detaljno, a odnosi se na različite tipove tradicionalnosti i modernosti žena. Druga varijacija teže je dostupna empirijskoj analizi, ali se njezino postojanje može pretpostaviti kao mogući nastavak autoričine interpretacije društvene raznolikosti 
žena, a riječ je o mogućnosti odvijanja jednoga duljega, premda vijugavog i prekidanoga, evolucijskog procesa emancipacije žena. Shodno tomu, valjalo bi pokušati objasniti narav veze između mnogolikosti žena i njihovih sudbina i izvjesne višesmjernosti modernizacije.

Bez sumnje, analitički postupak općenito ostaje ključnim izvorom novih spoznaja koje mogu dovesti u pitanje teorijska polazišta koja zanemaruju složenost procesa emancipacije žena, uguravajući je u shemu klasičnog modernizma. S druge strane, varijacije i raznolikost mogu biti dokazom višesmjernosti evolucije, prirodne i društvene. Taj je složeni proces na jedinstven način izložio Georg Simmel, opisujući grananje životne sile i njezine još neostvarene potencijale u ženskoj kulturi (Simmel, 2001: 100-102, 165-171; vidjeti i treću bilješku pod tekstom u ovom prilogu).

\section{Kritika klasičnog poimanja modernizacije}

Dakako, uz statistiku i klasifikaciju s odgovarajućom nomenklaturom, koju je ponudila autorica knjige, podjednako je važno oruđe spoznaje pojmovno-teorijski okvir. Različita objašnjenja društvenog procesa modernizacije u prethodnim desetljećima toliko su nabujala da je klasični teorijski okvir postao nedostatnim. Razlog je tome što je klasični okvir modernu potpuno odvojio od prethodnih epoha (u čemu je Georges Gurvitch /1965 [1950]/ među prvim sociolozima 20. stoljeća vidio jednu od glavnih zabluda klasične sociologije). Osim toga, dobar dio teorija modernizacije u 20. stoljeću, koje završavaju s Parsonsom i njegovom školom iz sedamdesetih godina tog stoljeća (usp. So, 1990) naglašeno je antimarksistička pa modernizaciju izjednačava sa širenjem ideologije liberalizma i društvenih vrijednosti zapadne gornje i srednje klase. Štoviše, brojne neuspjehe modernizacije u nezapadnim društvima te teorije u kolonijalističkom stilu pripisuju »nesposobnostima« tih društava.

Pozivajući se na najutjecajnije kritičare klasičnog poimanja modernizacije kao jednosmjernog i progresivnog kretanja - Tourainea, Becka, Giddensa, Ingleharta i Eisenstadta - Inga Tomić-Koludrović opredjeljuje se za poimanje modernizacije kao, u najvećem broju slučajeva, krivudavoga tranzicijskog procesa s dosta neizvjesnim ishodima, ali ipak s uvjerenjem da će moderni napredak kad-tad učiniti svoje. Pritom se jedno i drugo, sadašnji zastoji pa i nazadovanja te poboljšanje šansi većine ljudi u nekom budućem vremenu, ne moraju međusobno isključivati. Općenito izgleda da autorica, držeći se Beckova koncepta refleksivne modernizacije, čiji početak (i kraj) nije historiografski omeđen, osobito kad je riječ o europskoj periferiji, podrazumijeva da je modernizacija, braudelovski rečeno, proces neizvjesno dugog trajanja i s različitim »skretanjima«, opet barem kad je o (polu) periferiji riječ. S druge strane, stječe se dojam da je autorica skovala niz posebnih termina $^{1}$ koji opisuju značajne statističke varijacije u odgovorima žena, ali i u ci-

\footnotetext{
${ }^{1}$ Valja pohvaliti autoricu i izdavača na kazalu pojmova koje se još uvijek dosta rijetko izrađuje u domaćoj društvenoznanstvenoj publicistici.
} 
lju dopunjavanja specifične Beckove terminologije, ${ }^{2}$ za koju opet nije posve jasno naslanja li se na koncept pravocrtne modernizacije ili ga, slično Habermasu, Beck prebacuje u budućnost u smislu dugoročnog projekta, čiji je ishod, pak, neizvjestan shodno njegovu konceptu »nove modernosti« kao »društva rizika« (usp. Lasch i Wynne, 1992).

Jesu li i iskustva suvremenih žena u Hrvatskoj opterećena takvim rizicima zbog kojih one modernost ne prihvaćaju objeručke, nego je radije kombiniraju s tradicionalnim obrascima vrijednosti (kao sigurnijima?)? Iako vodi računa o modernizaciji kao strukturnoj promjeni u društvu, koja se očituje pomakom žena u socioekonomskom položaju i institucionalnom okviru društva (ustavom i zakonima zajamčena ravnopravnost moraju se potvrđivati u praksi, za razliku od jaza između normiranog i aktualnog oblika društvenog djelovanja u ranijem stadiju modernizacije) - autorica ipak daje prednost analizi društvene svijesti žena, osobito stoga što svijest dobiva prvorazrednu važnost u višem stupnju modernizacije, refleksivnoj modernosti. Na tom stupnju modernizacije žene postaju svjesne mogućnosti praktične izmjene uvjeta svog života. Tu se opet postavlja pitanje vraća li se time lik žene u jednu, okolnim putem »izduženu«, varijantu pravocrtnog modernizma. Za mnoge žene, uključujući dobar dio nezapadnog feminizma, uvredljiv je raniji emancipacijski stereotip po kojem bi žene trebale preuzeti stil zapadne žene ili zapadnog feminizma kao finalni uzor ženske samosvijesti. Međutim, ni autorica ove knjige niti njezino javnosociološko djelovanje ne upućuju na takav zaključak. Uostalom, različiti oblici ženske emancipacije i suvremenog feminizma toliko su se izdiferencirali - od liberalnog i socijalističkog do anarhističkog i vjerskog, a o unutrašnjim varijacijama i njihovoj prilagodbi u različitim područjima svijeta da $i$ ne govorimo - da se nijedan od tih oblika ne može smatrati jedinim ili istinskim uzorom cjelokupnoga ženskog mišljenja i djelovanja. Nadalje, autoričina analiza stavova žena u Hrvatskoj nije longitudinalna toliko da pruža dokaze o tome kako će se (samo)svijest žena i dalje mijenjati na crti tradicija - prva moderna - druga moderna. Tu se, doduše, iznova otvara pitanje o duljini trajanja modernizacijskog procesa i njegovim pretpostavkama: je li tu riječ o konjunkturnom i površinskom, takoreći »stilskom« fenomenu, ili dubljem i dugoročnom procesu društvenog preobražaja žena. Pouzdan odgovor na to pitanje možda će i trajno ostati predmetom spekulativnoga teorijskog razmatranja, budući da, koliko nam je poznato, ne postoje čvrsti empirijski pokazatelji dugoročnih tendencija kad je riječ o emancipaciji žena, kao subjektivnom i raznolikom izrazu njihova društvenog položaja. Usto, osim notornih problema s pokušajima predviđanja budućnosti, valja uzeti u obzir i ograničenost metodološkog nacionalizma koji sociologiju prati od osnivanja (gdje je društvo implicitno pojmljeno kao društvo u okviru pojedine države).

\footnotetext{
${ }^{2} \operatorname{Rad}$ je na rekonceptualizaciji modernizacijskih procesa u tekućoj literaturi uznapredovao i množe se novi termini, kao prva i druga (refleksivna) modernost, višestruka i paralelna modernost, rana i zrela tranzicija, a riječ modernosti sve se više piše u množini, osobito što se tiče kategorije roda u raznim područjima svijeta i društvenog djelovanja, od religije preko jezika i medija do političke sfere (usp. Herzog i Braude, 2009).
} 
U nastavku pokušavamo, razmišljajući o mogućim širim dimenzijama autoričine analize, koncipirati emancipaciju kao konvergentnu točku različitosti stavova žena, ali nakon što prokomentiramo najvažniji empirijski nalaz koji bi mogao toj pretpostavci ići u prilog.

\section{Ženski paradoks modernizacije u suvremenoj Hrvatskoj}

$\mathrm{U}$ analizi stavova svojih ispitanica autorica najprije upozorava da modernizacija nije pravocrtan ni kompaktan proces, da modernizacija jednog dijela nužno ne povlači sobom druge dijelove društva, barem ne u jednakoj mjeri. Isto vrijedi za retradicionalizaciju koja rijetko znači potpuno preuzimanje tradicije, nego prije novu varijaciju na istu temu.

Općenito je teško utvrditi kojoj istraživačici ili istraživaču pripada zasluga za otkriće najvećeg paradoksa modernizacije u hrvatskom društvu kad je riječ o ženama. U jednom od prvih longitudinalnih istraživanja autora Duška Sekulića (2012) na temu modernizacijskih procesa u Hrvatskoj pokazalo se da u cijelome postsocijalističkom razdoblju rastu religioznost, nacionalna isključivost i (politički i kulturni) konzervativizam, odnosno autoritarnost - osim u jednoj dimenziji, a to je rodni konzervativizam. Rodni konzervativizam, koji se odnosi na diskriminirajuće stavove prema ženama, suprotno očekivanjima, opada. Autor tu »anomaliju« objašnjava kao posljedicu zainteresiranosti političke ideologije za druga pitanja: »U onim dimenzijama koje su nešto udaljenije od tog ideološkog centra imamo [...] jasan trend prema modernijim stavovima.« (Sekulić, 2012: 256).

Kako pad rodnog konzervatizma u Hrvatskoj objašnjava Inga Tomić-Koludrović? Ona se oslanja na (Giddensovu) teoriju strukturacije, budući da takvo polazište, prema njezinu mišljenju, »otvara pitanje mogućnosti, odnosno poteškoća žena da se kao refleksivne akterice aktivno uključuju u proces proizvodnje i reprodukcije društvenog svijeta, te da na taj način pridonose strukturalnim transformacijama roda u hrvatskom društvu« (Tomić-Koludrović, 2015: 20). Pad rodnog konzervativizma stoga je moguće objasniti kao tendenciju, prije svega među ženama, da sve više (su)odlučuju o uvjetima svog života, privatnog i radno-profesionalnog, kako bi bile slobodne i izgrađivale istinski demokratsko društvo (za razliku od »demokracije« koja žene još uvijek isključuje iz političke i javne scene i važnijih mjesta u radnoj organizaciji). Pa ipak, činjenica jest da neke žene ne prihvaćaju modernost ili na nju gledaju s podozrenjem. Zašto je tako i ima li takva razložnost odgovarajuću misaonu kvalitetu u smislu slobodnog izbora? Dovodi li se time u pitanje modernizacijski proces ili ga se usporava ili, što se možda bolje uklapa u autoričin pristup, taj proces postaje raznovrsnijim? $?^{3}$

\footnotetext{
${ }^{3}$ Autoričin pristup svjetonazorski različitim ispitanicama nepristran je i uvažavajući, iako ona, razumljivo, ne dijeli svjetonazorske stavove svih ispitanica. Pa ipak, čini nam se da taj istraživački etos, osim što eliminira mogući »sukob interesa«, također pogoduje teorijskom polazištu koje ne naglašava samo raznolikost unutar (upitno jedinstvenog) obrasca modernizacije, nego i sve više izvjesnu raznolikost emancipacije.
} 


\section{Društveni tipovi žena u Hrvatskoj}

Autoričina analiza razlika u stavovima žena završava tipologijom, kao znanstveno najlegitimnijim načinom opisa društvenog fenomena. Iako podsjeća na najpoznatiju tipologiju žena, one Simone de Beauvoir u knjizi Drugi spol (Beauvoir, 2016 [1949]), u kojoj se opisuje pet karakternih tipova žena - podložnu, serioznu, nihilističku, pustolovnu i strasnu - sociološka tipologija ne polazi od karakternih crta (u većini slučajeva teško promjenjivih), nego iskustava stečenih u interakcijama s užom i širom društvenom okolinom, više ili manje moderniziranom, od navika ponašanja u obitelji do odnosa prema vladajućoj političkoj ideologiji i praksi. Tomić-Koludrović razlikuje društvene tipove žena na osnovi statističkih rezultata, čime dorađuje Beckovu binarnu tipologiju. Tako razlikuje patrijarhalnu ili predmodernu ženu (za koju je prirodno da muškarac u svemu ima glavnu riječ), onu tradicionalnu (unatoč zaposlenosti i radu izvan kuće, takva žena zadržava tradicionalna shvaćanja); treći tip je neodlučno-moderna žena (na prijelazu između tradicije i modernosti), a četvrti prijelazno refleksivni tip žene (iako zaposlena izvan kuće, smatra da može obitelji pružiti topli dom, kao i žene koje ostaju kod kuće, ali isto tako da su žene za obavljanje dvostruke ulogu sposobnije od muškaraca, što u nastavku pokušavamo prepoznati kao suvremeni izraz arhetipa heroine). U uzorku istraživanja nije bilo mjesta za potpuno refleksivni, rodno osviješteni, tip žene, što je razumljivo s obzirom na vrlo malen udio takvih žena u općoj populaciji. Pa ipak, stvari se miču s »mrtve točke« pa danas ni patrijarhalna seoska žena nije ista kao njezine pretkinje, ponajprije kad je posrijedi otvoreno izražavanje vlastitih stavova.

Najopsežnije, treće poglavlje knjige (ostala poglavlja sadržavaju podrobne analize stavova intervjuiranih žena prema temama plaćeni rad, obitelj, religija $\mathrm{i}$ politika) donosi niz zanimljivih pojedinosti. Autorica tako razlikuje dva čista $\mathrm{i}$ jednoznačna tipa žena, predmoderni i prijelazno-refleksivni, i dva mješovita i višeznačna, tradicionalni i neodlučno-moderni tip. Žena predmodernog tipa ima (u uzorku) $14,4 \%$ i one su dosljedno patrijarhalne u stavovima i smatraju da je za žene prirodno da odgajaju djecu i brinu se o kućanstvu, a muškarci rade izvan kuće i donose prihode kojima se obitelj izdržava. No, ovaj tip (stavova) ne samo da je rjeđi od ostalih, nego će se vjerojatno smanjivati zbog dinamike suvremenoga tržišnog gospodarstva koje koncentrira sve veće prihode u posjedu sve manjeg broja ljudi, što dovodi do opadanja prihoda sve većeg broja kućanstava. To se ponajprije odnosi na otkupne cijene poljoprivrednih proizvođača iz čega proizlazi da će i na selu samo jedan izvor prihoda (po pravilu muškarca) postati nedostatnim.

Tradicionalne žene $(33,8 \%)$ izložene su modernom utjecaju uglavnom zbog svoje zaposlenosti izvan kuće, ali su zadržale dosta elemenata tradicionalne svijesti kad je riječ o odnosima između superiornog muškaraca i inferiorne žene. Neodlučno moderni tip $(27,9 \%)$ ima također mješovita obilježja, ali je bliži tradicionalnosti i Beckovoj prvoj modernosti, dočim je prijelazno-refleksivni tip (24,6\%) bliži drugoj modernosti, što znači da u toj kategoriji žene približno razmišljaju kao moderne žene. 
Nadalje, žene starije dobi bliže su predmodernom i tradicionalnom, a mlađe žene neodlučnoj i prijelazno-refleksivnoj modernosti. Također, žene starije dobi relativno su manje obrazovane od žena mlađe dobi, što najviše utječe na stupanj (ne)modernosti u njihovim stavovima, a sličan je odnos među stavovima ispitanica iz selâ i gradova. Kad je riječ o regionalnoj distribuciji pojedinih tipova, nalazi nisu iznenađujući, budući da proizlaze iz distribucije prethodnih obilježja. Tako su žene predmodernog i tradicionalnog tipa najbrojnije u Lici (ukupno 72,6\%) i Slavoniji (62,6\%), a neodlučno modernog i prijelazno-refleksivnog tipa u Dalmaciji $(69,2 \%)$ te Zagrebu i Zagrebačkoj županiji (58,4\%). Napose, žena isključivo prijelazno-refleksivnog tipa najviše je u Zagrebu i Zagrebačkoj županiji (31,3\%) i Dalmaciji (30\%).

Dakako, pod pretpostavkom ujednačenijega daljnjeg ekonomskog razvoja i modernizacije, uključujući porast obrazovanja i mogućnosti zapošljavanja žena, mogu se očekivati daljnji pomaci u modernizaciji žena, kako njihova društvenog položaja tako i njihove (samo)svijesti po uzoru na zapadne žene. Pa ipak, na osnovi svih dosadašnjih empirijskih spoznaja, ne samo u ovoj knjizi nego i drugim istraživačkim radovima, o udjelima žena u procesima modernizacije u Hrvatskoj, nije lako zaključiti zbog čega u Hrvatskoj opada rodni, a rastu svi ostali konzervativizmi.

Iako je svoja prijašnja istraživanja provela na različitim uzorcima, autorica s priličnom pouzdanošću zaključuje da je u usporedbi s prijašnjim analizama, na primjer iz 1999. godine, i prema analizi temeljenoj na istraživanju iz 2005., došlo je do značajnog pomaka prema modernosti u svijesti žena. Doduše, nije došlo do formiranja nedvosmisleno refleksivnog ili metarefleksivnog tipa žena, koje mogu i doista su spremne dovesti u pitanje sve tradicionalno diskriminirajuće norme ponašanja koje se odnose na žene. Ali, da je i taj stupanj svijesti nešto što će se vjerojatno mijenjati među mnogim ženama (u nekoj mjeri i muškarcima) ne treba sumnjati, naravno ukoliko nas ne zadesi kakva prirodna ili ekonomska katastrofa koja skupa s emancipacijom žena dovodi u pitanje sva civilizacijska dostignuća.

\section{O mogućnostima potpunijeg objašnjenja ženskog paradoksa}

U svakom slučaju, Inga Tomić-Koludrović pružila je dodatne dokaze o opadanju rodnog konzervativizma u Hrvatskoj s time što je dublje rasvijetlila slojevitost pa i izvjesnu proturječnost tog procesa, budući da i u trenutačno najnaprednijoj kategoriji, onoj prijelazno-refleksivnih žena, ima tragova tradicionalne svijesti. No, utoliko je autoričin opis modernizacijskog procesa gušći i relevantniji od onih koji još uvijek posežu za jednostavnom dihotomijom tradicionalno - moderno. Uostalom, oštrog raskida između moderne i tradicionalne epohe nije bilo ni u postrevolucionarnim razdobljima (usp. Skocpol, 1979).

Preostaje još pokušati odgovoriti na pitanje zbog čega opada rodni konzervativizam te stoji li objašnjenje prema kojem svijest i položaj žena u društvu nisu tema od interesa za parlamentarne političke stranke, da na popularnosti u očima žena ne grade svoj ugled u društvu (možda to pitanje u jednom još uvijek patrijarhalnom 
društvu, prožetom demokratskom hipokrizijom, stranke smatraju kontraproduktivnim?). Zbog očitog krivudanja modernizacijskog procesa, uslijed čega je upitno pogoduje li i kad modernizacija ženama, valja pretpostaviti da emancipacija žena ne izvire samo iz konjunkturnih (najčešće desetogodišnjih) procesa ekonomskog rasta (ili pada) ili iz prevage određene političke opcije. Čini se čak da je emancipacijski proces donekle imun na takve trendove, iako ne i na katastrofalne situacije, uključujući rat ili naglo i široko ekonomsko propadanje društva. Obje katastrofe koje su se udružile, na primjer, u suvremenim zbivanjima na Bliskom i Srednjem istoku nikako ne idu u prilog većini žena, muškaraca i njihovih obitelji.

Sličnih je tektonskih poremećaja u društvu bilo mnogo i to više kako idemo u dalju prošlost, ponajprije zbog učestalosti nepredvidivih klimatskih i ekonomskih promjena, kao i ratova. Do davnih vremena, međutim, teško dopiru instrumenti povijesnih istraživanja, a o sociološkim istraživanjima da se ne govori, pa je praktički nemoguće rekonstruirati način na koji su žene u tim vremenima mislile o sebi, muškarcima i drugim temama. Vjerojatno su bile mnogo konzervativnije u svojim stavovima i požrtvovnije nego većina njihovih potomkinja. Ali, ni naše pretkinje vjerojatno nisu bile jednodušne u svojim razmišljanjima ni svaki put dosljedne u praksi, a zacijelo su bile sposobnije od muškaraca prilagoditi se različitim i otežavajućim okolnostima. ${ }^{4}$ Uspjeh u njihovu procesu prilagodbe na obiteljske i vanjske okolnosti bio je krivudav kao i suvremeni modernizacijski proces, što se odnosi i na demokratski proces (ako se o njemu uopće može govoriti kao nečemu otvorenom za javnost, budući da se po pravilu odvija ispred, a ne iza kulisa). Također, nisu se tek s modernom epohom žene i ljudi općenito počeli suočavati s teškoćama koje proizlaze iz kršenja pravila igre i različitih oblika nasilja jačih nad slabijima.

Prema tome, može se pretpostaviti da emancipacija žena traje dulje od moderne epohe, kao evolucijski proces koji dijelom koegzistira s modernizacijskim procesima, pri čemu nešto od modernih obrazaca uzima, a nešto odbacuje, privremeno ili trajno, ovisno o dijelovima zemlje ili društva o kojem je riječ. Na mogućnost gledanja na proces modernizacije žena kao dionicu jednoga dugotrajnijeg razvojnog procesa, bliskijeg sagledavanju povijesti jednog Fouriera ili Marxa (koji smatraju da se napredak civilizacije može vjerodostojno mjeriti /samo/ napretkom

\footnotetext{
${ }^{4}$ Brojni, raznoliki i zahtjevni oblici prilagodbe žena vjerojatno su uzrokovali razvitak vrsta inteligentnog mišljenja i djelovanja (od verbalnog izražavanja do multiaktivnosti, ali i gomilanja i hologramskog oblikovanja prešutnog znanja koje se najčešće ubraja u skupni, ali sadržajno nedovoljno jasan, pojam intuicija) u mnogo većoj mjeri nego u muškaraca koji su se većinom specijalizirali u pojedinim senzornim, motoričkim i intelektualnim aktivnostima i cjelokupnoj podjeli rada. Ako je dosadašnja evolucija stavljala žene u sjenu muškaraca, daljnja će ih evolucija zacijelo razvrstati na raznovrsnija mjesta. Međutim, (naj)sposobniji ljudi ne zauzimaju nadređeni položaj, što je u uskoj vezi s osvajanjem formalne vlasti, zbog čega dolazi do atrofije niza drugih sposobnosti. Stoga se korak naprijed koji su žene učinile, vjerojatno davno prije većine muškaraca, zahvaljujući raznovrsnijoj inteligenciji te osobnom senzibilitetu koji omogućuje sigurniju procjenu prednosti i nedostataka situacije u društvenom okruženju, neće utjeloviti u bilo kojem dosad poznatom obliku hijerarhijske vlasti, nego prije u indirektnoj i fleksibilnoj kontroli vlasti.
} 
u društvenom položaju žena), knjiga Inge Tomić-Koludrović pruža barem neizravne dokaze, koje omogućuje znanstvena empirija, a to je izvjesno oklijevanje u iznošenju sudova koji bi mogli upućivati na to da sugovornica (u intervjuu) iznosi koherentan svjetonazor, koji je otvoreno nalik određenoj doktrini, što je za većinu ljudi koji posve ne kontroliraju uvjete svog življenja riskantna gesta. Na primjer, većina žena u Hrvatskoj vjerojatno izražava svoju privrženost crkvenim naučavanjima. Jedan od najjačih razloga za to jest osjećaj izvjesne sigurnosti, biti pod okriljem tako moćne ustanove, bez obzira na njezin diskriminirajući stav prema ženama. Slično je sa stavovima većine žena prema domu i odgajanju djece, koji im pružaju veću sigurnost ili zadovoljstvo od sudbine na (prilično divljem) tržištu rada. Donekle je sličan refleks među manjinama u Hrvatskoj koje se osjećaju sigurnijima kad njihovi predstavnici koaliraju sa strankama tradicionalno nesklonim »drugima«. Ali, u svim se tim slučajevima ljudi uglavnom ne ponašaju kao agenti vlasti ili glasnogovornici neke ideologije, ne samo zato što je dobro ne poznaju, nego i zato što ideologije pokazuju istu vrstu nedosljednosti, više ili manje pragmatičnu, kao i ljudi u svojim razmišljanjima o važnim temama.

Može se pretpostaviti da su zbog istih razloga - prilagodbe na društvene situacije koje su im nametnute ili se ne mogu okrenuti u njihovu korist - mnoge žene sklone izražavati ambivalentan stav spram (konzervativnih, liberalnih ili socijalističkih) demokratskih stranaka u Hrvatskoj, budući da im se u Hrvatskoj ne pružaju čvrsta jamstva u smislu ekonomskog opstanka. Slično je iskustvo s novim privatnim poslodavcima i njihovim uvjetima rada. Na temelju svega toga ipak se ne može izvući zaključak da su žene sklone konzervativizmu ili povlačenju iz svijeta rada. Ako u nekim sredinama to i jesu u većoj mjeri nego drugima, ni takav stav nije nedvosmislen i trajan, nego prilagođen danoj situaciji i koristan onoliko koliko im vanjsko okruženje pruža podršku u rješavanju mnoštva problema s kojima se žene nose u mikrosvjetovima svog života i rada. U njima, na dulje staze, od starih tradicija do danas, ipak doživljavaju više uspjeha nego neuspjeha. To je jedini dokaz emancipacijske usmjerenosti u procesu društvene evolucije žena, koja kroči naprijed, ali oprezno i uz koji korak natrag. I vjerojatno zbog takvih kombiniranih strategija oslobađanja, koje ne poništavaju tradiciju, nego je integriraju u složeniji oblik prilagodbe kao dobrodošli oslonac, žene intervjuirane u ovom istraživanju ne doživljavaju brak i obitelj kao smetnju svojim planovima. Ako jednom njihove kćeri zakorače smjelije i iziđu na veliku scenu te postanu javno vidljivijima nego ikada prije, vjerojatno će taj iskorak uslijediti kao rezultat solidno argumentiranog i najracionalnijeg izbora. Sveukupno, emancipacija žena rezultat je postupnog porasta životnih šansi koje ne proizlaze prvenstveno iz povoljnih situacija na tržištu rada ili kampanja povećanja ženskih kvota u politici ili upravljanju poduzećima, nego iz situacija koje takav iskorak čine manje rizičnim, kao rezultat porasta dugo vremena nevidljivih uspjeha žena u bezbrojnim stanicama društvenog života.

Inga Tomić-Koludrović svakako ne misli kao njezine ispitanice, ali pokazuje da dobro razumije njihovu nedosljednost u razmišljanjima $i$ da tu nije riječ o kognitivnoj pogreški: »Pokazalo se da, iako žene visoko vrednuju moderne emancipirane stavove o važnosti zaposlenja za smisleni život žene, nešto manje, ali ipak 
prilično visoko, vrednuju i predmoderne i tradicionalne stavove.« (Tomić-Koludrović, 2015: 43).

\section{Kako bi muškarci odgovorili na pitanja koja se tiču žena?}

Ako je riječ o ambivalentnosti svojstvenoj suvremenoj ženskoj svijesti u Hrvatskoj (iako ne samo u Hrvatskoj), nameće se nimalo suvišno pitanje bi li muškarci u analognim intervjuima dali odgovore slične intervjuiranim ženama. Možemo pretpostaviti da ne bi, jer se (kod većine muškaraca) radi o drukčijem habitusu i položaju u društvu i različitim iskustvima u rasponu od uloga u kućanstvu do učestalosti zlostavljanja na radnom mjestu na poslu. Razmišljajući na taj način, dade se pretpostaviti da bi razlike u stavovima među muškarcima bile manje značajne i odgovori bi bili bliži kako »čistim« kategorijama tradicionalnoga (na primjer, u smislu da je ženi doista mjesto samo u kući) tako i modernog shvaćanja u smislu prvenstvene zainteresiranosti i orijentiranosti muškarca, koji pripadaju srednjoj i gornjoj društvenoj klasi, na ekonomski ili karijerni uspjeh, čemu bi kod muškaraca radničke klase i seljaka odgovaralo stjecanje prihoda iz različitih, npr. "polùtānskih«, oblika rada. Drugim riječima, dihotomija - formulirajmo to kao jednu hipotezu - tradicionalno - moderno bila bi oštrija nego među ženama. ${ }^{5}$ Stoga je moderni prototip junaka ipak junakinja. Samo tzv. superžene mogu »žonglirati« svojom energijom i raspoloživim vremenom na jednoj i drugoj strani, u obitelji i na poslu. I u ovoj studiji, podsjetimo se, nemali broj ispitanica izražava stav po kojem su samo žene sposobne izvoditi takve podvige.

Takav habitus ne odgovara toliko Bourdieuovu pojmu habitusa, koliko Simmelovu zapažanju s početka 20. stoljeća o sposobnostima žena, iznesenom u ondašnjoj Njemačkoj, u kojoj su samo rijetki intelektualci slutili epohalnu katastrofu uzrokovanu prevlašću muške, prema Simmelu, objektivizirane kulture (što je opisao kao »tragediju kulture«). Štoviše, on ženskim vrijednostima pridaje neobičnu postojanost u modernoj eri koja po definiciji daje prednost nepostojanom i prolaznom (»sve što je čvrsto pretvara se u dim«). Uz to Simmel (2001) ženskim vrijednostima pridaje i transcendirajuće značenje. ${ }^{6} \mathrm{U}$ skladu $\mathrm{s}$ takvim poimanjem

\footnotetext{
${ }^{5}$ Ali odgovori ne bi, kao ni u drugim istraživanjima s uključenom varijablom spola, bili posve drukčiji, jer se biološke razlike nigdje u svijetu ne preklapaju s kulturnim razlikama u smislu obrazaca vrijednosti i ponašanja. Preciznije rečeno, u takvoj anketi neki bi odgovori ili polja značenja bili identični i zajednički ženama i muškarcima.

${ }^{6}$ Valja usporediti i sljedeća dva odlomka iz referirane knjige. Prvi je o životnoj sili: »Dok sve neživo naprosto posjeduje samo sadašnji trenutak, ono živo proteže se na neusporediv način preko prošlosti i budućnosti [...] u svojoj sadašnjosti sadrži svoju budućnost, u posebnoj formi čiji je opstanak sadržan upravo samo u životnom procesu (Simmel, 2001: 24). Drugi odlomak govori o potencijalima žene: »Žena se nije samo vrlo rano, na osnovi jednog metafizičkog pojma razvoja, opisivala kao 'mogućnost' nasuprot kojoj bi tek muškarac bio 'zbilja', nego se [...] čini da njezino biće sadrži toliko neozbiljenih mogućnosti, neispunjenih obećanja, sputanih snaga, da bi to biće tek njihovim razvojem u aktivnost dolazilo do svoje odredbe, posve očitovalo svoje vrijednosti i postignuća (Simmel, 2001: 172). Treba li još dometnuti zaključak koji proizlazi iz navedenih odlomaka, naime da je
} 
može se zaključiti da naizgled neuračunljiva ktonička božanstva - shvaćanje koje proizlazi iz žilavog stereotipa o varljivosti žena - u osnovi djeluju konvergentno u cilju preživljavanja ljudi.

\section{Epilog: ženski hologrami u različitim slojevima kulture}

Veliki raspon stavova žena o vlastitom položaju i izgledima u društvu uzimamo kao povod za epilog o potrebi za proširenjem nazivlja za opis varijacija u njihovim stavovima, iako takvi opisi često predstavljaju nemoguću zadaću pretvaranja, takoreći, brojki u slova. Tako nijednom nomenklaturom nije moguće obuhvatiti svaki interval iz ogromnog ili beskonačnog niza brojeva. Što se tiče načina imenovanja intervalâ, postavlja se pitanje treba li imenovati samo one entitete koji proizlaze iz manjih ili one iz većih razlika / intervala u postocima ili se zadovoljiti samo rečeničnim opisivanjem varijacija unutar jedne te iste kategorije. U svakom slučaju nedostajat će naziv na mjestu najmanjih razlika u postocima, premda je »najmanje« prije kvalitativna, nego kvantitativna kategorija, budući da je riječ o značajnosti koja ima smisla samo unutar određene, nazovimo je tako, prirodnojezično formulirane teorije, odnosno tipologije. Tako nedostaje naziv ili termin za pretežno ili u manjoj mjeri u stavovima nedosljednu »tradicionalnu ženu« ili »pretežno (ne) dosljednu refleksivnu ženu«. To iziskuje izvjestan »dramaturški« zahvat u analitički jezik društvenih istraživanja (što nastojimo ilustrirati primjerima u nastavku). Inga Tomić-Koludrović pokušala je, čini se, ta semantički prazna mjesta riješiti izvjesnim »požurivanjem« vremena na tranzicijskom putu, pretpostavkom koja vjerojatno proizlazi iz Beckove teorije koja nesumnjivo podupire modernistički optimizam, iako na stupnjevit način, a to je da će unatoč varijacijama, uključujući zastoje i nazadovanja, u ne tako dalekoj budućnosti, većina žena postati »refleksivno modernima«, dakle sačinjavati poveću kategoriju ljudi (recimo bihevioralnih »Šveđanki« i »Šveđana« na hrvatski način) unutar koje varijacije više nisu toliko važne kao na »nižem« stupnju (prve) modernizacije. S druge strane, nedostatak kvalitativnog termina, neke ženske imenice ili sintagme, u odnosu na kvantitativne razlike, odnosno brojke koje zamjenjuju prirodnojezične termine, podsjeća na povijesnu anonimnost različitih društvenih gomila (tko je ili što, na primjer, izve/1/o bilo koju nasilnu društvenu revoluciju i položi/l/o najviše života za njezine ideale?) i praktično svih žena u povijesti koje su se dugo nalazile ili se još uvijek nalaze u jako dugom tunelu (u kojem samo modernistički optimisti vide izlaz s danjim svjetlom). ${ }^{7} \mathrm{~S}$ druge strane, brojevi možda ukazuju na praznine na

muškarac upravo s modernom epohom dostigao svoj vrhunac koji graniči s pretovarenošću stvarima (Simmelov izraz za »objektivnu kulturu«) i prijetnjom neživoga, tj. uništenja, a da je na ženi zadaća produljenja života u još neviđenim oblicima (raznolikosti)?

${ }^{7}$ Bezimenost nedinastijskih žena odraz je njihove nepoznatosti, kao i namjernog poricanja i potiskivanja u zabilježenoj povijesti. Jedno od najbanalnijih mjesta utvrđivanja beznačajnosti žena jesu križaljke. U njima se žensko ime po pravilu izvodi dodavanjem slova $a$, prema imenu nekoga poznatog muškarca ili samo nepoznatom imenjaku, a mnogo rjeđe obratno. 
jezično zaboravljenim mjestima, ali vjekovne praznine, uslijed čega su se nataložili slojevi intuitivne spoznaje koji razlučuju, možda i imenuju, mnogo više pojava u svijetu života ili široj stvarnosti od modernih ljudi, poput brojnih izraza u finskom i još više eskimskom jeziku za različite vrste snijega, ususret beskonačnosti koju je kao teorijsku pretpostavku otvorila gramatika indeksiranog (formalnog) jezika (Chomskyjeva hijerarhija) i koja je, prema Hegelu, loša ako se u njoj ponavlja jedno te isto, kao u mitskim slikama paklenskih muka ili vremenskim petljama $\mathrm{u}$ suvremenoj kinematografiji.

U nastavku navodimo neke primjere pokušaja prevladavanja tog problema putem konceptualne terminologije, naime kako ili kojim (prirodnojezičnim) nazivima označiti raznolikost rodnog fenomena, koja unatoč imenovanju još uvijek ostaje jezično neiscrpnom.

Prvi primjer upućuje na pravu muku suvremenih istraživača u potrazi za nazivima vezanim za spolno-rodne varijacije, koje uz to nisu isključivo moderni, pa ni samo ljudski, oblici ponašanja ${ }^{8}$ Promotrimo stoga s dužnim oprezom, imajući na umu mogućnost periodičnog nastajanja ili nestajanja pojedinih oblika iz raznolikog spektra roda kao spola ili zbog smanjenja ili povećanja učestalosti imenovanih oblika, raspon sljedećih naziva kojima se označavaju pojedine rodno-spolne kategorije primijenjene (i već prije korištene u raznim istraživanjima) na osnovi 114 odgovora transseksualnih mormona u SAD-u (Sumerau, Cragun i Mathers, 2016: 294): rod binarno, transrodno, cisrodno (termin za prilagodbu na rodni identitet i seksualnost koju nameće društvo), cisseksizam (stav superiornosti u odnosu na transrodnost), cisnormativnost (ideologija kojom se diskriminiraju transrodni identiteti), ze, zir, hir (rodno neutralne zamjenice), transmuškarac, transžena, međuspol (identitet ljudi koji biološki ne pripadaju isključivo u muško ili žensko), rodno varijatni/fluidni/queer, arodni, dvorodni, trans (oznaka za ukupni nekonformizam).

Autorice tog istraživanja napominju da popis termina može biti dulji, osobito zato što je riječ o društvenim konstrukcijama koje se mijenjaju u ovisnosti o situaciji. U svakom slučaju, termini se podjednako odnose na žene i muškarce, koji se često, prema istoj kolonijalnoj praksi, izjednačavaju s rodovima. Shodno širem i slobodnijem poimanju, međutim, termini roda mogu se umnožavati ne samo s obzirom na različite društvene situacije nego i oblike skupne pripadnosti, klasne, nacionalne, religijske, seksualnomanjinske i tako dalje. Na primjer, pitanje je bi li se ista ili slična distribucija rodnih kategorija pojavila u slučaju istraživanja žena ili muškaraca katolika, protestanata ili muslimana, izostavljajući metodološke poteškoće s obzirom na stupanj (ne)iskrenosti ispitanika u odgovorima, bilo da je posrijedi njihova (ne)spremnost da razotkriju svoj identitet ili pak (ne)sigurnost s obzirom na vlastita ili »prava« uvjerenja (ukoliko tako nešto uopće postoji među većinom ljudi). U tom pogledu, postupak Inge Tomić Koludrović, kojim

\footnotetext{
${ }^{8}$ Prije dolaska europskih kolonizatora, američki urođenici razlikovali su pet rodnih kategorija. Portretist urođenika, slikar George Caitlin, izjavio je da se tom kuriozitetu, koji su urođenici poštovali kao tradiciju Dvaju duhova, treba zatrti svaki trag prije nego što se vijest o toj tradiciji proširi među kolonizatorima (Brayboy, 2016).
} 
je »skalirala« odgovore ispitanica, poigravajući se s Beckovim terminom »refleksivne modernizacije«, posve je opravdan. A kako bi se i moglo drukčije označiti grupiranje njihovih stavova nego u većini slučajeva kao pojedinih trans-kategorija (koje potencijalno prelaze jedna u drugu, optimistički govoreći, iz tradicionalnih $\mathrm{u}$ moderne)? Podsjetimo da je za autoricu tranzicija također problematičan (teleološki) termin, barem što se tiče posljedica (hipotetskog) prijelaza iz jednoga u drugi političko-ekonomski sustav.

Izvorni primjer ženske raznolikosti pojavljuje se, kad je riječ o kolonijalnoevolucionističkoj perspektivi, na najmanje očekivanom mjestu, u najranijim oblicima religijske svijesti zabilježenih kultovima paleolitskih predaka koji se arheološki očituju u mnoštvu galerija »Venerinih« figurica. Iako su dugo označavane kao dokaz prirođene sklonosti monoteizmu, u vidu »pramonoteizma« najranijih primitivnih društava (usp. Jensen, 1963), daleko je prikladnije na fenomen ženskih figura gledati kao plastično predočavanje pojavne raznolikosti ženskog roda, prije svega mnogostrukost ženskih funkcija, a potom njihove važnosti ili ugleda koji je svakako visok u tom razdoblju ljudskog društva koje nije, kako bi kazao Simmel, pretovareno artefaktima objektivne (muške) kulture. Likovi žena koji se pojavljuju u najmanje dvanaest različitih tjelesnih položaja (vidjeti u nastavku odlomka) ne samo da nemaju veze s monoteizmom, nego pretpostavljeno najviše biće pokazuju u obličjima koja potpuno odudaraju od načina predstavljanja Gospodara Neba i Zemlje u patrijarhalnim monoteističkim religijama. Sljedeći su nazivi korišteni prilikom jedne velike izložbe posvećene prikazima kulta žena u najstarijem paleolitiku (Shadmi, 2015: 4-5): žena koja rađa, žena koja stoji (klanska majka ili dea gentrix), žena u drugom stanju, žena koja doji, majka totemskih životinja i biljaka, žena koja zaziva nebo i androgina osoba. Nakon ledenog doba pojavljuju se likovi u još pet položaja: blagoslovljujući, žalopojni i plačući, moleći, ponekad s podlakticama i dlanovima ispred trbuha (dea regeneratrix) i žensko dvojstvo ili trojstvo.

Iz tog se niza ne može izlučiti kolonijalno-evolucionistički stereotip o ženi, koji zaposjeda i sužava povijesno-vremensku perspektivu zaključkom da su žene u pradavno matrifokalno doba bile daleko važnije (muškarcima i društvu u cjelini) nego poslije toga ili sve do danas. Takvo razumijevanje proturječi činjenicama. Doduše, suvremene žene, u odnosu na žene kamenog doba, jesu u društveno podređenom položaju u odnosu na muškarce. Međutim, to ne znači da na takav položaj dragovoljno pristaju, a ni to da obavljaju beskorisne poslove za društvo. Ti su poslovi itekako korisni, ali ih društvo, izgrađeno na osnovi patrijarhalnog mita i prakse moći (o »prvotnosti« muškarca), malo ili nimalo ne cijeni. Uza sve to, kao što ističu neke sugovornice u knjizi Pomak prema modernosti, one se $\mathrm{s}$ dvostrukim teretom dužnosti, kod kuće i na poslu, snalaze daleko bolje nego što bi to mogli muškarci. Isto tako, za razliku od muškarca, bilo supruga, partnera na poslu ili premijera, žena svoju moć radije skladišti nego što demonstrativno pokazuje. Također, muškarac ima vlast, kao formalnu i reprezentativnu razinu moći (nad dijelom društva ili čitavim društvom), ali nema toliku moć koju ima žena koja uloge u svojoj sredini i svoje veze s drugima hologramski oblikuje kako bi oslobodila prostor za stvaranje novih oblika zajedničkog opstanka. 
Treći odabrani primjer diskretne ženske raznolikosti odnosi se na djelo Dom Bernarde Albe Frederica Garcíje Lorce. Scena se stvara iza zatvorenih vrata kuće i pod prigušenim svjetlom s jasno diferenciranim središnjim ženskim likovima u turobnoj atmosferi nakon pogreba supruga, oca i gospodara kuće. U jednom trenutku u prvom činu, prema autorovoj didaskaliji, na scenu izlazi dvije stotine žena u crnini (kao tamni podzemni masiv neizmjernog suosjećanja), a potom izlazi glavni lik, Bernarda, u pratnji pet kćeri (Angustije, Magdalene, Amelije, Martirije i Adele). U njihovim razgovorima ocrtava se središnji dramski krug napetosti, koja više otkriva dublje i često potiskivane stavove, nego reakcije na trenutačnu situaciju. Muškarci se spominju, no nijedan se ne pojavljuje na sceni. Imena prisutnih žena imaju prepoznatljiv etimološki korijen koji služi označavanju njihovih karakternih osobina. Pored spomenutih, u drami se pojavljuju Maria Josefa (Bernardina majka), Poncia (sluškinja), Criada Prudencia (sluškinja) te bezimena sluškinja, bezimena djevojka, bezimena prosjakinja i četiri bezimene žene (označene rednim brojevima). Imenovane žene su, pak, karakterološki razrađene - u rasponu od »žene-mučenice« potisnutih osjećaja kao u »muškarca« (Martirio) do majke (Bernarde), koja utjelovljuje gotovo sve iz galerije ženskih likova, od materinskog do varijacija između ženskog i muškoga, ucviljene žene i gospodarice koja pokušava zamijeniti autoritet pokojnog supruga (Lorca, 2010 [1936]).

Izneseni primjeri - Lorcini individualni sižei potresenih žena, figure arhetipske Venere te izrada rodno-seksualnog nazivlja - podsjećaju na konceptualne figure žena u knjizi Inge Tomić-Koludrović. Zajednički im je fokus isticanje raznolikosti i protivljenje stereotipima, uključujući jednosmjerno shvaćenu modernost kao epohu koja sve više baca u sjenu čitavu prethodnu prošlost, od arhaičke do predmoderne. Ostaje otvorenim pitanje da li se autorica, preuzimajući Beckov pojam »refleksivna modernost« (ili druga modernost), kao najviši stadij dosadašnjega sociokulturnog razvitka, zaobilazno (»krivudajući«) vratila klasičnom poimanju modernosti. U tom bi se slučaju moglo podrazumijevati i to da su tradicionalne žene misaono prikraćene. Doduše, stupanj obrazovanja bez sumnje ima utjecaja na (samo)svijest žena, ali to ne mora biti presudno u svim pa ni većini slučajeva. Poznavanjem ne samo ovog djela nego i dosadašnjih autoričinih djelâ i njezin istraživački rad, kao i akademsku i javnu orijentaciju, ne bi se moglo reći da, lingvistički rečeno, kulturu niskog konteksta, kao što je visokoobrazovna (elaboriranog kôda), stavlja »iznad« kulture visokog konteksta (restriktivnog kôda). Prije bi se moglo zaključiti da se i u refleksivnoj modernosti, što demonstrira i autoričin fleksibilan pristup procesu emancipacije, prožet obzirnošću prema ispitanicama različitih svjetonazora, neke žene svojevoljno i promišljeno vraćaju tradicionalnoj ulozi, premda ne u autentičnom tradicijskom obliku. Prošlost je ipak ono što je dobrim dijelom prošlo ili se obnavlja u preobraženom obliku i, dakako, ne s istim posljedicama kao nekada. Prema tome, gotovo uvijek imamo posla s varijacijama na temu modernosti. Isto značenje može i ne mora imati retradicionalizacija u svim islamskim društvima, što osobito vrijedi za mnoge obrazovane žene s hidžabom koje su običaj prihvatile, bilo slobodno bilo pod nekim oblikom prisile, nakon reislamizacije društva. No, žene su, zbog strogosti običaja usredotočenog na žensko ponašanje, vjerojatno u manjem broju slučajeva svojevoljno prihvatile nikab, a u najmanjem broju burku. 
Stoga bi se emancipacija mogla, simbolički govoreći, odvijati u smjeru hidžaba ili asimilacije obrazaca žena Zapada, ali ponovo s cijelom lepezom varijacija.

Dakako, iz presjeka ženske svijesti prikazane u knjizi Inge Tomić-Koludrović ne mogu se izvući dalekosežni zaključci koji bi bili empirijski potkrijepljeni. Čak je teško pretpostaviti da će se ikada moći prikupiti dovoljno empirijske građe za izradu dugoročnih predviđanja. Pa ipak, naši spoznajni interesi za širi ili budući svijet ne jenjavaju zbog metodoloških ograničenja. To je epistemološko pravo na svojevrstan način utvrdio kasni Popper, kao postpozitivistički »treći svijet« predmetne spoznaje u kojem se, osim ostalih, nalaze mitovi, umjetnička djela i društvene institucije. U svakom slučaju ti su fenomeni povezani dubljim vezama od senzorno opažljivih kao što su objektivni predmeti (usp. Popper, 1978). Stoga slobodnije razmišljanje nije nelegitimno, dakako ako se logički dodiruje i nastavlja na zaključke izvedene iz empirijske studije. U tom je smislu ova knjiga poticajna, a zacijelo će usmjeravati i buduća longitudinalna istraživanja o modernizacijskima procesima u Hrvatskoj, osobito kad je riječ o ženama.

Pokušajmo na kraju - s nekoliko pogodbenih rečenica umjesto premisa i provizornim umjesto čvrstim zaključkom, koji intonacijom podsjeća na Simmelovu eulogiju ženskoj kulturi - skicirati obećavajuću žensku putanju u procesu (post) modernizacije i izgradnji civilizacije u cjelini. Onog trenutka, naime:

- kad završi kapilarna emancipacija ženskih kvaliteta ljudskog roda i osmotskom se difuzijom prometne u glavne razvojne procese društva,

- kad žene, prema sociološkoj viziji Janet Saltzman Chafetz (1990, 2006), na kraju »trećeg vala« emancipacije uđu u sve društvene elite i preuzmu nadzor u vrhovima vlasti koja se u predugoj eri između primitivnih društava i suvremenog društva, otuđila od prirode i čovjeka,

- kad opet, ali na nov način, žene uspostave odnos ljubavi spram svijeta, ne samo svom potomstvu po rođenju nego i zajedničkoj pripadnosti onoj velikoj svjetskoj zajednici čiju većinu pripadnika, prema analogiji s pojmom »nacija« Benedicta Andersona, ne poznajemo niti ćemo ih ikada upoznati, a ipak vjerujemo da pripadamo toj istoj zajednici (Anderson, 1990 [1983]),

- kad se potomkinje i potomci naših majki, sestara, kćeri i unukâ i njihovih idućih naraštaja pojave na pozornici koja će zamijeniti paleolitsku galeriju koju su žene napustile radi reprodukcije i odgajanja potomstva u sve težim okolnostima proizvedenima rastućom složenosti društva i širenjem novih i novih oblika poretka izrabljivanja i nasilja nad ljudima i prirodom,

- nakon što su tijekom desetaka tisuća godina opstojnosti primitivnih društava trajno utisnule svoj generativni lik u kolektivnu svijest čovječanstva, neprekidnom i podjednakom usredotočenošću na funkcionalne i transcendirajuće kvalitete ženskog oblika življenja upisanog u njezinom tijelu, plodnom i lijepom spremištu mudrosti čije poruke podjednako dopiru do privilegiranih i do zapostavljenih,

- kad se, kao što je predviđao Simmel, oslobode ženske kvalitete kao najveći ljudski potencijali, koje se danas nanovo otkrivaju u potrazi za formulama održivog razvoja,

tada svijet neće, doduše, postati savršenim, ali će postati razumnijim, pravednijim i ljepšim. 


\section{LITERATURA}

Anderson, Benedict (1990 [1983]). Nacija: zamišljena zajednica. Razmatranja o porijeklu i širenju nacionalizma. Zagreb: Školska knjiga.

Beauvoir, Simone de (2016 [1949]). Drugi spol. Zagreb: Naklada Ljevak.

Brayboy, Duane (2016). »Two Spirits, One Heart, Five Genders«, Indian Country Today, 23. siječnja. http://indiancountrytodaymedianetwork.com/2016/01/23/ two-spirits-one-heart-five-genders.

Gurvitch, Georges (1965 [1950]). Savremeni poziv sociologije. Sarajevo: Veselin Masleša.

Herzog, Hanna i Braude, Ann (2009). »Introduction: Untangling Modernities«, u: Hanna Herzog i Ann Braude (ur.). Gendering Religion and Politics: Untangling Modernities. New York: Palgrave Macmillan, str. 1-17. doi: $10.1057 / 9780230623378$

Jensen, Adolf Ellegard (1963). Myth and Cult Among Primitive Peoples. Chicago: University of Chicago Press.

Lasch, Scott i Wynne, Brian (1992). »Introduction«, u: Ulrich Beck. Risk.Society: Towards a New Modernity. London: Sage, str. 1-8..

Lorca, Frederico García (2010 [1936]). Teatralije. Zagreb: Demetra.

Popper, Karl (1978). Three Worlds: The Tanner Lecture on Human Values. Ann Arbor: University of Michigan.

Saltzman Chafetz, Janet (1990). Gender equity: An integrated theory of stability and change. Newbury Park: Sage.

Saltzman Chafetz, Janet (ur.) (2006). Handbook of the Sociology of Gender. New York: Springer.

Shadmi, Erella (2015). »Divine Surprise, the Female Side of God«, u: Erella Shadmi (ur.). Mothers' Path: Motherhood, Capitalism and Feminism. Tel Aviv: Verlag Resling, str. 1-17.

Sekulić, Duško (2012). »Društveni okvir i vrijednosni sustav«, Revija za sociologiju 42 (3): 231-275. doi: 10.5613/rzs.42.3.1

Simmel, Georg (2001). Kontrapunkti kulture. Zagreb: Naklada Jesenski i Turk i Hrvatsko sociološko društvo.

Skocpol, Theda (1979). States and Social Revolutions: A Comparative Analysis of France, Russia, and China. Cambridge: Cambridge University Press.

So, Alvin Y. (1990). Social Change and Development: Modernization, Dependency and World-System Theories. London: Sage.

Sumerau, J. E., Cragun, Ryan T. i Mathers, Lain A. B. (2016). „Contemporary Religion and the Cisgendering of Reality«, Social Currents, 3 (3): 293-311. doi: $10.1177 / 2329496515604644$

Tomić-Koludrović, Inga (2015). Pomak prema modernosti: žene u Hrvatskoj u razdoblju »zrele« tranzicije. Zagreb: Naklada Jesenski i Turk i Hrvatsko sociološko društvo. 